\title{
Review of Hygiene and Disinfection Recommendations for Outpatient Glaucoma Care: A COVID Era Update
}

\author{
Julie M. Shabto, BA, ${ }^{*}$ Carlos Gustavo De Moraes, MD, MPH, PhD, $†$ \\ George A. Cioffi, MD, † and Jeffrey M. Liebmann, $M D \dagger$
}

\begin{abstract}
This review focuses on best practices and recommendations for hygiene and disinfection to limit exposure and transmission of infection in outpatient glaucoma clinics during the current COVID-19 pandemic.
\end{abstract}

Key Words: coronavirus, disinfection, hygiene, glaucoma, tonometry, visual field testing, optical coherence tomography, lenses

( J Glaucoma 2020;29:409-416)

$\mathrm{T}^{\mathrm{h}}$ he first physician to sound the alarm about the novel coronavirus causing severe acute respiratory syndrome coronavirus 2 (SARS-CoV-2) was ophthalmologist Lin Wenliang, MD in Wuhan, China. Not long after he first raised awareness for SARS-CoV-2, he was infected by a presymptomatic patient with glaucoma and died. ${ }^{1}$

Just a few months after Dr Wenliang's death, several studies have confirmed both presymptomatic and asymptomatic transmission of SARS-CoV-2 $-2^{2-5}$ and the director of the Centers for Disease Control and Prevention (CDC) Dr Robert Redfield estimates that as many as $25 \%$ of individuals who test positive for COVID-19 disease are asymptomatic. ${ }^{6}$ Hence, the fear of transmission of SARS-CoV-2 during an ophthalmology office visit is well warranted and requires ophthalmologists, optometrists, and ancillary personnel to be aware of the signs and symptoms of COVID-19; and to minimize transmission to personnel and other patients.

Reports have suggested that COVID-19 may present with findings of conjunctivitis that are indistinguishable from viral conjunctivitis because of other pathogens. A study of 30 patients in China found that 1 patient with conjunctivitis had SARS$\mathrm{CoV}-2$ in tear film and conjunctival discharge, suggesting that the virus may cause infection through the conjunctiva or ocular surfaces. $^{7}$ In a study of 38 patients with clinically confirmed COVID-19, ocular findings such as conjunctival hyperemia and epiphora were associated with more severe clinical disease, higher white blood cell, and neutrophil counts, and greater

Received for publication April 13, 2020; accepted April 17, 2020.

From the *Emory University School of Medicine, Atlanta, GA; and

$\dagger$ Edward S. Harkness Eye Institute, Columbia University Irving Medical Center, New York, NY.

Supported by Bernard and Shirlee Brown Glaucoma Research Laboratory, Edward S. Harkness Eye Institute, Columbia University Irving Medical Center, New York, NY and an unrestricted grant from Research to Prevent Blindness, New York, NY (Columbia University Department of Ophthalmology)

Disclosure: The authors declare no conflict of interest

Reprints: Carlos Gustavo De Moraes, MD, MPH, PhD, Edward S. Harkness Eye Institute, Columbia University Irving Medical Center, 635 W 165th Street, Box 69, New York, NY 10032 (e-mail: cvd2109@cumc.columbia.edu).

Copyright (C) 2020 Wolters Kluwer Health, Inc. All rights reserved.

DOI: 10.1097/IJG.0000000000001540
C-reactive protein elevation compared with patients without ocular symptoms. ${ }^{8}$ Though the risk of ocular transmission of SARS-CoV-2 through the tear film is likely low, ${ }^{9}$ the use of ophthalmic diagnostic equipment and procedures that requires close proximity to patients - such as the slit lamp, ophthalmoscope, and ocular manipulation -increases the risk of viral transmission from patient to physician through respiratory droplets and contact with surfaces. In addition, several ophthalmic instruments are commonly used during a single-patient visit and, if not disinfected properly, these tools can become potential sources of transmission.

There were nearly 46.3 million office visits to ophthalmologists in the United States in 2016 according to the most recent CDC National Ambulatory Medical Care Survey. ${ }^{10,11}$ Glaucoma, 1 of the top 5 reasons for office visits, accounted for 7.19 million visits in the United States in 2016. ${ }^{11}$ The large volume of annual office visits to outpatient glaucoma clinics combined with the use of ophthalmic tools and the necessary proximity of physicians to patients during these visits puts both patients and health care workers at considerable risk for exposure to pathogens. Moreover, patients visiting a glaucoma clinic are often older adults with comorbidities, ${ }^{12,13}$ the demographic at highest risk of severe illness from COVID-19. ${ }^{14}$

How can glaucoma specialists adjust their practice to best protect themselves from exposure to SARS-CoV-2 and avoid becoming a vector for transmission to patients and staff? Through an internet search and communication with ophthalmic equipment manufacturers, we have compiled recommendations for hygiene and disinfection in outpatient glaucoma clinics as a reference guide. The Ophthalmology Department at Columbia University implemented many of these practices before the American Academy of Ophthalmology (AAO) or the CDCpublished guidelines for outpatient care. Following the development of an operational task force at Columbia University, the Ophthalmology Department shared several commonsense measures for practice operations starting March 2. The department has continued to be proactive in adjusting best practices for ophthalmology clinics, and these updated protocols and policies, including a Patient Visit Stratification, are publicly available on the department's COVID-19 Information webpage. ${ }^{15}$

\section{PREVENTING PERSON TO PERSON TRANSMISSION IN GLAUCOMA OUTPATIENT SETTINGS}

The primary mode of transmission of SARS-CoV-2 is thought to be person to person spread in respiratory droplets when an infected person coughs, sneezes, or talks. ${ }^{16}$ To limit respiratory spread during office visits, ophthalmologists must take precautions to regulate the number of patients entering clinic, to preserve social (physical) 
distancing, and to minimize direct encounters between staff and patients. ${ }^{17-20}$

The CDC has published guidelines for health care facilities to protect patients and staff during the current SARS-CoV-2 outbreak. ${ }^{21}$ These recommendations include screening patients for symptoms of acute respiratory illness -including cough or shortness of breath, sore throat, or systemic symptoms like myalgias or chills - and advising patients to check their temperature before their arrival at the health care facility, asking all patients about history of travel to areas with high prevalence of COVID-19 or contact with possible COVID-19 positive individuals, separating patients with respiratory symptoms from other patients in the waiting area, optimizing the use of telemedicine, limiting the number of staff providing care, installing barriers to limit contact with patients during triage, and emphasizing hand hygiene for patients and staff. ${ }^{22,23}$

On March 18, 2020, the AAO published "New Recommendations for Urgent and Nonurgent Patient Care," 24 urging ophthalmologists to halt providing any treatment that is nonurgent or nonemergent. The AAO is continually updating their guidelines for practice management specific to ophthalmology. In addition to the aforementioned CDC recommendations, AAO recommendations include the following ${ }^{24}$ :

- Reschedule appointments for patients with nonurgent ophthalmic problems and see only patients with emergent needs or those requiring frequent management.

- Only allow patients inside the practice; if necessary, a patient may have only 1 person to accompany them. ${ }^{25}$

- Encourage online payment of copays to minimize interaction between patients and health care staff.

- Use slit lamp breath shields.

- Both patient and physicians should speak as little as possible during slit lamp examination.

- For patients with documented COVID-19, persons under investigation, or patients who are "potentially infected with COVID-19," ophthalmologists should wear personal protective equipment (PPE) including an N95 mask, gown, gloves, and eye protection.

Although the CDC suggests implementing PPE optimization strategies to extend supplies, ${ }^{26}$ at the moment this review was performed, the AAO has not yet offered an official stance on the use and reuse of PPE. The recommendations and expectations for the use of PPE in the outpatient glaucoma clinics must be considered in the context of the United States' PPE shortage. For example, N95 masks are not currently readily available for outpatient health care settings, so the AAO has not yet recommended the use of $\mathrm{N} 95$ masks in outpatient clinics. CDC guidance should be followed and accessed frequently given our constantly changing knowledge of disease transmission. The purpose of this review is to provide a resource for the disinfection of instruments and devices of particular interest to the glaucoma specialist.

\section{DISINFECTION OF THE CLINIC ENVIRONMENT: WAITING ROOM AND PATIENT ROOMS}

Another important mode of transmission of COVID19 may be spread from contact with contaminated surfaces or objects. ${ }^{16}$ To minimize disease transmission through surfaces in the outpatient health care setting, both the CDC and AAO recommend routine cleaning and disinfection of waiting rooms, restrooms, examination lanes, office furniture, and instruments. ${ }^{23,27}$ For example, within the Ophthalmology Department at Columbia University, cleaning of check-in and check-out kiosks, front desk workstations, door entries, and waiting room furniture is performed hourly. ${ }^{28}$

The AAO suggests following CDC recommendations for appropriate disinfectant agents, which include: diluted household bleach ( $>1000 \mathrm{ppm}$ sodium hypochlorite), alcohol solutions with at least $70 \%$ alcohol, and common EPA-registered household disinfectants (eg, surface wipes with dimethyl benzyl ammonium chloride, such as Clorox and Lysol branded products). ${ }^{27}$ The EPA published an official list of products that meet criteria for use against SARS-CoV-2 and includes the required amount of time that a surface should be treated with each product to effectively kill the virus. ${ }^{29}$

\section{DISINFECTION OF EQUIPMENT AND OTHER INSTRUMENTS IN GLAUCOMA CLINICS}

Another potential vector of transmission in glaucoma clinics is any device used during patient visits. Slit lamps are commonly discussed in the context of viral transmission given the close proximity of patient to provider and patient-instrument contact during the physical examination. The AAO has encouraged the use of slit lamp breath shields, and several manufacturers including Zeiss and Topcon are offering free slit lamp breath shields. There are also many videos and picture demonstrations on the internet for how to make functional slit lamp breath shields using materials that are easily accessible, such as an A4 plastic folder or a plastic quilting template. Other ophthalmic devices such as handheld tonometers have been implicated in the transmission of viral pathogens as well. ${ }^{30}$

On April 2, 2020, the AAO recommended using the "same disinfection practices already used" to disinfect ophthalmic instruments and office furniture. ${ }^{27}$ In order to confirm manufacturers' disinfection instructions and to provide a reference tool for glaucoma specialists as they continue to see patients in the outpatient setting, customer support lines of several manufacturers were contacted, and we conducted a comprehensive review of manufacturer webpages and equipment user manuals.

We have compiled the cleaning and disinfection instructions from manufacturers for the following ophthalmic tools that are commonly used in outpatient glaucoma clinics: visual field analyzers (Table 1), optical coherence tomography (OCT) machinery (Table 2), tonometers (Table 3), and lenses (Table 4). Each table is inclusive of commonly used products from a sample of manufacturers but is not meant to be an exhaustive list nor an endorsement of the listed products. The information provided herein is publicly available as of April 5, 2020 on manufacturer websites or as downloadable PDF documents.

\section{VISUAL FIELD TESTING}

Visual Field Analyzers of all types require close contact of the patient to the equipment and close proximity of the operator to the patient and equipment (including data entry and patient positioning). Aspects of the equipment that come into direct contact with the patient include the forehead and chin rests, the patient response button, the chair, and the eye occluder. The corrective lens may also come into contact with the patient's eyelashes or nose. Respiratory droplets may accumulate on these surfaces and importantly within the perimetry bowl itself. The duration of viral particle presence on the bowl surface, how long the particles remain suspended within the bowl, and whether the viral particles can be dislodged or resuspended by normal breathing or talking by the patient undergoing testing is 


\begin{tabular}{|c|c|c|c|c|}
\hline Manufacturer & Haag-Streit Diagnostics & Heidelberg Engineering Inc. & OCULUS Inc. & Carl Zeiss Meditec Inc. \\
\hline \multirow[t]{5}{*}{ Products } & Octopus perimetry 600 & Heidelberg Edge Perimeter & Easyfield C & Humphrey Field Analyzer 3 \\
\hline & Octopus Perimetry 900 & & Easyfield S & Perimetry \\
\hline & & & Centerfield 2 & \\
\hline & & & Smartfield & \\
\hline & & & Twinfield 2 & \\
\hline \multirow[t]{3}{*}{$\begin{array}{l}\text { Materials for } \\
\text { disinfection }\end{array}$} & Desinset from HAAG-STREIT & $\begin{array}{l}\text { Optical surfaces: dry } \\
\text { microfiber cloth }\end{array}$ & $\begin{array}{l}\text { Pursept-A Xpress } \\
\text { (alcohol-based) } \\
\text { disinfectant cloths or } \\
\text { an equivalent }\end{array}$ & $\begin{array}{l}\text { Liquid Trial Lens: soft cloth } \\
\text { or tissue }\end{array}$ \\
\hline & & $\begin{array}{l}\text { Never use cleaning tissues or } \\
\text { disinfectant wipes to clean } \\
\text { the lens }\end{array}$ & & $\begin{array}{l}\text { Forehead and chin rests, } \\
\text { patient response button, } \\
\text { exterior surfaces, touch } \\
\text { screen: dampened soft } \\
\text { cloth }\end{array}$ \\
\hline & & $\begin{array}{l}\text { Nonoptical surfaces: moist } \\
\text { cloth }\end{array}$ & & $\begin{array}{l}\text { Bowl: cotton-tipped } \\
\text { applicator }\end{array}$ \\
\hline \multirow[t]{5}{*}{$\begin{array}{l}\text { Agents for } \\
\text { disinfection }\end{array}$} & $70 \%$ isopropyl alcohol & $\begin{array}{l}\text { Optical surfaces: isopropyl } \\
\text { alcohol with an alcohol level } \\
\text { of } 70 \% \text { or ethanol with an } \\
\text { alcohol level of } 80 \%\end{array}$ & $\begin{array}{l}\text { Do not use aggressive, } \\
\text { chlorine-containing } \\
\text { abrasive or sharp } \\
\text { cleaning agents }\end{array}$ & $\begin{array}{l}\text { Liquid Trial Lens: } 70 \% \\
\text { isopropyl alcohol in water } \\
\text { or mild glass cleaner } \\
\text { containing no ammonia }\end{array}$ \\
\hline & $\begin{array}{l}\text { Do not use solvents or abrasive } \\
\text { cleaning products }\end{array}$ & $\begin{array}{l}\text { Nonoptical surfaces: Metrex } \\
\text { CaviWipes or other EPA- } \\
\text { registered disinfectants with } \\
\text { comparable active } \\
\text { substances }\end{array}$ & & $\begin{array}{l}\text { Forehead and chin rests, } \\
\text { patient response button: } \\
\text { mild detergent, alcohol } \\
\text { wipes }\end{array}$ \\
\hline & & $\begin{array}{l}\text { Follow appropriate infection } \\
\text { control guidelines regarding } \\
\text { surface disinfectant contact } \\
\text { times }\end{array}$ & & $\begin{array}{l}\text { Bowl: } 70 \% \text { isopropyl alcohol } \\
\text { in water }\end{array}$ \\
\hline & & $\begin{array}{l}\text { Do not use products } \\
\text { containing acetone or } \\
\text { hydrogen peroxide }\end{array}$ & & $\begin{array}{l}\text { Exterior panels: mild } \\
\text { detergent or appliance } \\
\text { cleaner }\end{array}$ \\
\hline & & & & $\begin{array}{l}\text { Do not spray cleaner directly } \\
\text { on the touch screen or } \\
\text { exterior surfaces }\end{array}$ \\
\hline \multirow[t]{2}{*}{$\begin{array}{r}\text { Frequency of } \\
\text { disinfection }\end{array}$} & $\begin{array}{l}\text { Forehead and chin rests, patient } \\
\text { response button, eye patch, } \\
\text { corrective lenses, and patient-side } \\
\text { cover should be disinfected before } \\
\text { every examination and after each } \\
\text { patient use }\end{array}$ & $\begin{array}{l}\text { Disinfect the device before } \\
\text { and after each examination }\end{array}$ & $\begin{array}{l}\text { Disinfect the forehead } \\
\text { and chin rests, } \\
\text { handheld button, and } \\
\text { eyepatch after each } \\
\text { examination }\end{array}$ & $\begin{array}{l}\text { Disinfect the forehead and } \\
\text { chin rests and patient } \\
\text { response button after each } \\
\text { patient }\end{array}$ \\
\hline & & & $\begin{array}{l}\text { Disinfect the housing } \\
\text { as needed }\end{array}$ & $\begin{array}{l}\text { Bowl: disinfect small spots } \\
\text { on bowl surface due to } \\
\text { patient coughing or } \\
\text { sneezing }\end{array}$ \\
\hline \multirow[t]{2}{*}{$\begin{array}{l}\text { Links to user } \\
\text { manuals for } \\
\text { reference }\end{array}$} & $\begin{array}{l}\text { www.haag-streit.com/haag-streit- } \\
\text { diagnostics/products/perimetry/ } \\
\text { octopus-900/ }\end{array}$ & $\begin{array}{l}\text { PDF available upon request } \\
\text { from manufacturer }\end{array}$ & $\begin{array}{l}\text { PDF available upon } \\
\text { request from } \\
\text { manufacturer }\end{array}$ & $\begin{array}{l}\text { www.zeiss.com/content/ } \\
\text { dam/med/ref- } \\
\text { international/corona/pdfs/ } \\
\text { ifu-cleaning-excerpt- } \\
\text { hfa3.pdf }\end{array}$ \\
\hline & $\begin{array}{l}\text { www.haag-streit.com/haag-streit- } \\
\text { usa/products/haag-streit- } \\
\text { diagnostics/octopus-perimetry/ } \\
\text { octopus-600/ }\end{array}$ & & & $\begin{array}{l}\text { www.zeiss.fr/content/dam/ } \\
\text { Meditec/international/ifu/ } \\
\text { documents/hfa3/current/ } \\
\text { 2660021166131_a_ } \\
\text { artwork.pdf }\end{array}$ \\
\hline
\end{tabular}

unknown. The eye occluder may be replaced with disposable material such as taped gauze or an amblyopia patch to decrease the amount of time and material used for disinfection between each patient. Disinfection of visual field analyzers including the bowl surface may be difficult, and the AAO previously suggested avoiding the use of "equipment that cannot be safely disinfected, such as some visual field analyzers." 24 Routine perimetry should therefore be performed judiciously and taking into account the aforementioned precautions. A summary of the recommendations for cleaning and disinfection of visual field analyzers is provided in Table 1.

\section{IMAGING DEVICES (OCT)}

Imaging devices' (eg, OCT or cameras) forehead and chin rests come into direct contact with the patient. The exterior surface of the machine may be contaminated by a patient's respiratory droplets from breathing or speaking during the examination. A summary of the recommendations for cleaning and disinfection of OCT units is provided in Table 2. 
TABLE 2. Summary of Recommendations for the Cleaning and Disinfection of Common Optical Coherence Tomography Devices, by Manufacturer

\begin{tabular}{|c|c|c|c|c|}
\hline Manufacturer & Heidelberg Engineering Inc. & Optovue Inc. & $\begin{array}{l}\text { Topcon Medical } \\
\text { Systems Inc. }\end{array}$ & Carl Zeiss Meditec Inc. \\
\hline Products & SPECTRALIS & $\begin{array}{l}\text { iVue, iFusion, Avanti, } \\
\text { iScan }\end{array}$ & $\begin{array}{l}\text { Maestro } 2 \\
\text { Swept Source DRI OCT } \\
\text { Triton }\end{array}$ & $\begin{array}{l}\text { CIRRUS } 6000 \\
\text { CIRRUS } 5000 / 500\end{array}$ \\
\hline \multirow[t]{2}{*}{$\begin{array}{l}\text { Materials for } \\
\text { disinfection }\end{array}$} & $\begin{array}{l}\text { Optical surfaces: dry microfiber } \\
\text { cloth }\end{array}$ & $\begin{array}{l}\text { Ocular (Front Objective) } \\
\text { lens: lens cleaning paper }\end{array}$ & $\begin{array}{l}\text { Lens: } 100 \% \text { cotton high- } \\
\text { performance wipe wrapped } \\
\text { around long cotton tip } \\
\text { applicator, air puffer }\end{array}$ & $\begin{array}{l}\text { Do not use alcohol prep } \\
\text { wipes to clean lenses or } \\
\text { optical surfaces }\end{array}$ \\
\hline & $\begin{array}{l}\text { Never use cleaning tissues or } \\
\text { disinfectant wipes to clean the } \\
\text { lens }\end{array}$ & $\begin{array}{l}\text { Head and chin rest: cloth } \\
\text { or cleaning towels, wet } \\
\text { isopropyl alcohol } \\
\text { cleaning paper pad }\end{array}$ & & $\begin{array}{l}\text { Optics: soft, absorbent, lint- } \\
\text { free lens tissue wrapped } \\
\text { around a cotton swab }\end{array}$ \\
\hline \multirow[t]{4}{*}{$\begin{array}{l}\text { Agents for } \\
\text { disinfection }\end{array}$} & $\begin{array}{l}\text { Nonoptical surfaces: moist cloth } \\
\text { Optical surfaces: isopropyl } \\
\text { alcohol with an alcohol level } \\
\text { of } 70 \% \text { or ethanol with an } \\
\text { alcohol level of } 80 \%\end{array}$ & $\begin{array}{l}\text { Ocular (Front Objective) } \\
\text { lens: diluted acetone or } \\
\text { lens cleaning solution }\end{array}$ & $\begin{array}{l}\text { Lens: } 3 \mathrm{M} \text { Novec } 7200 \\
\text { Engineered Fluid }\end{array}$ & $\begin{array}{l}\text { Nonoptical surfaces: } \\
\text { spectroscopic grade } \\
\text { isopropyl alcohol or } \\
\text { acetone }\end{array}$ \\
\hline & $\begin{array}{l}\text { Nonoptical surfaces: Metrex } \\
\text { CaviWipes or other EPA- } \\
\text { registered disinfectants with } \\
\text { comparable active substances }\end{array}$ & $\begin{array}{l}\text { Head and chin rest: } \\
\text { antigermicide or } \\
\text { isopropyl alcohol }\end{array}$ & $\begin{array}{l}\text { Nonoptical surfaces: } \\
\text { disinfecting wipes }\end{array}$ & $\begin{array}{l}\text { Strong solvents such as } \\
\text { acetone or methyl alcohol } \\
\text { will damage the chin cup } \\
\text { and forehead rest }\end{array}$ \\
\hline & $\begin{array}{l}\text { Follow appropriate infection } \\
\text { control guidelines regarding } \\
\text { surface disinfectant contact } \\
\text { times }\end{array}$ & & & $\begin{array}{l}\text { Lenses: water, isopropyl } \\
\text { alcohol, and acetone }\end{array}$ \\
\hline & $\begin{array}{l}\text { Do not use products containing } \\
\text { acetone or hydrogen peroxide }\end{array}$ & & & $\begin{array}{l}\text { Do not use alcohol prep } \\
\text { wipes to clean lenses or } \\
\text { optical surfaces } \\
\text { Do not use any cleaning } \\
\text { agent on the screen }\end{array}$ \\
\hline $\begin{array}{l}\text { Frequency of } \\
\text { disinfection }\end{array}$ & $\begin{array}{l}\text { Disinfect the device before } \\
\text { and after each examination }\end{array}$ & $\begin{array}{l}\text { The headrest pad and chin } \\
\text { rest cup should be } \\
\text { cleaned before every } \\
\text { patient visit } \\
\text { Ocular (front objective) } \\
\text { lens of the RTVue } \\
\text { should be cleaned daily }\end{array}$ & Not specified & $\begin{array}{l}\text { The forehead and chinrests } \\
\text { should be cleaned between } \\
\text { each examination }\end{array}$ \\
\hline $\begin{array}{l}\text { Links to user } \\
\text { manuals for } \\
\text { reference }\end{array}$ & $\begin{array}{l}\text { PDF available upon request } \\
\text { from manufacturer }\end{array}$ & $\begin{array}{l}\text { PDF available upon } \\
\text { request from } \\
\text { manufacturer }\end{array}$ & $\begin{array}{l}\text { www.topconmedical.com/ } \\
\text { customersupport/ } \\
\text { instructional.htm }\end{array}$ & $\begin{array}{l}\text { www.zeiss.com/content/dam/ } \\
\text { med/ref_international/ } \\
\text { corona/pdfs/ifu-cleaning- } \\
\text { excerpt-cirrus-6000.pdf }\end{array}$ \\
\hline
\end{tabular}

\section{TONOMETRY}

\section{Contact Tonometry}

Previous studies have reported that applanation tonometry has the potential to transmit a variety of infectious agents, including adenovirus 8 and herpes simplex virus 1 , and reusable tonometer prisms could, in theory, be a mode of transmission for hepatitis B, hepatitis C, human immunodeficiency virus, and Creutzfeldt-Jakob disease. ${ }^{31-37}$ A systematic review of 11 studies assessing the disinfection of Goldmann tonometers concluded that there is no definitive optimal technique or agent for the disinfection of Goldmann applanation tonometer prisms. ${ }^{30,33}$ The AAO supports the use of diluted bleach for the disinfection of reusable tonometer tips for SARS-CoV-2 and adenovirus. If available, single use, disposable tonometer prisms provide an alternative to reusable prisms to prevent cross-contamination. ${ }^{38}$ A summary of the recommendations for cleaning and disinfection of common contact tonometers is provided in Table 3.

\section{Noncontact Tonometry}

In its Infection Prevention and Control Recommendations, the CDC suggests taking precautions when performing aerosol- generating procedures, which could generate the aerosolization of viral particles. ${ }^{23}$ A 1991 study using florescence photography using specific types of tonometer (Keeler Pulsair and AO NCT II) depicted visible tear film splatter from the air puff in eyes receiving fluorescein drops; however the investigators were unable to demonstrate aerosolization of the tear film in eyes not receiving topical drops. ${ }^{39}$ Unless aerosolization of the tear film with the puff energy elicited by the current devices is evidenced, noncontact tonometry during the pandemic could be considered after weighing risks and benefits. One potential benefit, for instance, is that these tonometers permit more staff-patient distancing than other methods. When used, care should be taken to properly disinfect contact surfaces between patients.

\section{LENSES}

Given their frequent handling, proximity to respiratory droplets and/or direct contact to the eye, diagnostic, or therapeutic lenses [eg, handheld indirect lenses (20D, 28D, 60D, 78D, 90D, etc.) Goldmann-type contact lenses, laser surgery lenses, gonioscopy lenses, and others] are vectors for nosocomial infection during an ophthalmologic examination. ${ }^{40,41}$ 
TABLE 3. Summary of Recommendations for the Cleaning and Disinfection of Common Contact Tonometers, by Manufacturer

\begin{tabular}{llll}
\hline Manufacturer & Haag-Streit Diagnostics & Icare USA Inc. & Reichert Inc.
\end{tabular}

\section{Keeler Ltd}

Products $\quad$ AT 900 Goldmann Applanation Tonometer

Materials for disinfection

Agents for

disinfection

\section{HAAG-STREIT's Desinset}

Hydrogen peroxide at a $3 \%$ aqueous solution or sodium hypochlorit (household bleach) at a 10\% aqueous solution

Do not use agents containing alcohol or acetone, do not disinfect using UV radiation, do not sterilize using steam or ethylene oxide, and do not expose to temperatures $>60^{\circ} \mathrm{C}$

Frequency of disinfection

Links to user manuals for reference

Not specified

www.haag-streit.com/fileadmin/HaagStreit_Diagnostics/Tonometry/ Instructions_for_use/Disinfection/ 01-IFU Desinfektion-7220375 04060_eng 01.pdf

www.haag-streit.com/fileadmin/HaagStreit_Diagnostics/Tonometry/ Instructions_for_use/List_of

Disinfectants/SHT_DisinfectionList7200533-04210.pdf
Icare ic100 Tonometer

Icare ic200 Tonometer Icare TA01i

Damp soft cloth

70\%-100\% isopropyl alcohol, mild soap solution, or $95 \%$ Pursept solution

Bleach may discolor the handle

Never spray, pour or spill liquid onto the Icare tonometer, its accessories, connectors, switches, or openings in the chassis. Dry any liquid on the surface of the tonometer immediately

Clean the forehead and cheek support for each new patient Clean the probe base every 6 mo

www.icare-usa.com/wp-content/ uploads/2017/10/Icare_Cleaning Instructions.pd
Tono-Pen AVIA

Tono-Pen XL Tonometer

CT 100 and CT210 Contact Tonometer

Ocular Response Analyzer G3

PT100 Portable Noncontact Tonomete

Model 30 Pneumatonometer

Soft cloth

External surfaces and forehead rest: mild detergent solution ( $1 \mathrm{cc}$ of liquid dish soap to $1 \mathrm{~L}$ of clean, filtered water (filtered below $5 \mu \mathrm{m}$ )

Measurement prism: aqueous hydrogen peroxide solution of $3 \%$

Operator display: neutral detergent, isopropyl, or ethanol. Do not use any chemical solvent, acidic, or alkali solution on the operator display

PT100: do not use alcohol, methanol, acetone, or any other solvents when cleaning the PT100

Clean Tono-Pen body between patients

Measurement prisms should be disinfected before each use

http://doclibrary.com/MSC167/PRM/ 16170-101-Rev-J-UG-ORAG31553.pd

http//doclibrary.com/MSC167/PRM/ 68E3441-Rev-K-XL-UG0700.pdf

http://doclibrary.com/MSC167/PRM/ 12598-101-Rev-E-CT210-UG3818.pdf
TonoCare Noncontact Tonometer AccuPen Handheld Tonometer

Pulsair intellipuff Tonometer KAT R-Type and T-Type Keeler Applanation Tonometers

D-KAT R-Type and T-Type Applanation Tonometers

Soft nonshedding cloth

Tonometer body: water/detergent solution ( $2 \%$ detergent by volume) or water/ isopropyl alcohol solution (70\% IPA by volume)

Tonometer prisms: Pantasept $-3 \%$ aqueous solution, hydrogen peroxide $3 \%$ aqueous solution, or sodium hypochlorite, $10 \%$ aqueous solution

Do not disinfect prisms using the following: alcohol, acetone, UV radiation,

sterilization, immersion in fluid for $>1 \mathrm{~h}$, temperatures $>60^{\circ} \mathrm{C}$

TonoCare puff tube lens: water/detergent solution ( $2 \%$ detergent by volume)

Avoid using isopropyl alcohol solution on optical surfaces

Clean the hand unit daily and between patients

Clean and disinfect prism before each use

www.keelerusa.com/pub/media/ productattachments/files/k/a/kat_ver_ d_-_english.pdf

www.keelerusa.com/pub/media/ productattachments/files/e/P/ep5970038-art-f_english.pdf

www.keelerusa.com/pub/media/ productattachments/files/P/u/pulsair intelipuff_ver_f_-_english.pdf 
TABLE 4. Summary of Recommendations for the Cleaning and Disinfection of Common Lenses, by Manufacturer

Manufacturer Haag-Streit Diagnostics Ocular Instruments Inc.

\section{Volk Optical Inc.}

\section{Indirect BIO lenses}

Noncontact slit lamp lenses

Indirect $\mathrm{BIO}$ lenses

Suture lysis lenses

Ocular koeppe diagnostic gonio lenses

Lint-free tissues or hospital grade

compressed air for drying

\section{Materials for}

Agents for

disinfection

\section{Desinset from HAAG-STREIT}

$3 \%$ aqueous solution of hydrogen peroxide or $10 \%$ aqueous solution of sodium hypochlorite (household bleach)

Do not use agents containing alcohol or acetone, do not disinfect using UV radiation, and do not sterilize using steam or ethylene oxide, do not expose to temperatures $>60^{\circ} \mathrm{C}$

Contact lenses may be treated together with each other, but not with any other products

Frequency of Clean and disinfect contact lenses before Each device requires cleaning and

disinfection each use

www.haag-streit.com/fileadmin/HaagStreit_Diagnostics/Tonometry/

Links to user manuals for reference

For all Ocular MaxField Glass and disinfection before each use

For all Ocular Argon/Diode, YAG and Diagnostic Lenses: clean with low foaming mild soap then disinfect with a disinfectant solution approved by the U.S. Food and Drug Administration (FDA), the German Society of Hygiene and Microbiology (DGHM), CE Mark, etc. Pay strict attention to disinfectan manufacturers recommended

concentrations and contact durations. To avoid damage to the lens, do not exceed recommended exposure time MaxLight CR-39 Indirect Diagnostic/ Laser Lenses: clean with alcohol wipe, then proceed with disinfection as above

To avoid surface damage to contact lenses, never clean the contact elements with alcohol, peroxide or acetone

Instruments should be cleaned as soon as possible after use to minimize the drying of contaminants to the surface before initial use and between uses. Do not allow the lens to dry after use. Immediately decontaminate the lens after use

https://ocularinc.com/media/wysiwyg/pdf/ https://volk.com/pdf/CCG-001-Cleaning- www.katena.com/support/instructions10781_Cleaning_Method_1_English_ Only_Rev_H.pdf for-use

01-H__Desinfektion-7220375-04060

eng_01.pdf

www.haag-streit.com/fileadmin/Haag-

Streit_Diagnostics/Tonometry/

Instructions for use/List of

Disinfectants/SHT_DisinfectionList-

https://ocularinc.com/media/wysiwyg/pdf/

10781_Cleaning_Method_1_English_

Only_Rev_H.pdf

7200533-04210.pdf 
In order to limit the number of patients coming into contact with a single lens, many ophthalmology departments, including our own, have suspended the use of trial lenses and trial framing, and are only performing refractions in rare situations. ${ }^{28}$ Singleuse diagnostic or therapeutic lenses, such as those offered by some manufacturers (eg, Volk Optical and Katena), can reduce the potential for transmission of infection and eliminate the time required for disinfection without affecting image quality. ${ }^{42,43}$ Alternatively, Haag-Streit Goldmann lenses can be used with an optically neutral disposable shield call the Stery Cup. ${ }^{44}$ A summary of the recommendations for cleaning and disinfection of lenses commonly used in an office visit for a glaucoma patient is provided in Table 4.

\section{CONCLUSIONS}

There are many opportunities for the transmission of pathogens, particularly the coronavirus now causing COVID-19, during a patient visit to an outpatient glaucoma clinic. Proper infection control practices are especially important given the volume of patients in these clinics - even during times of restricted patient flow - and the number of instruments that may be used during a single-patient examination. Careful attention to personal hygiene, social (physical) distancing, and instrument disinfection will decrease the chance of inadvertent transmission among ourselves, office personnel, and patients in the outpatient setting.

By implementing many of these practices in the first week of March, before national organizations gave recommendations for outpatient clinical practices, our department has kept the COVID-19 infection rate among staff and faculty very low. This proactive approach serves as an example for how Ophthalmology Departments can effectively address the next epidemic or pandemic to decrease transmission between patients and providers.

\section{REFERENCES}

1. Parrish RK II, Stewart MW, Duncan Powers SL. Ophthalmologists are more than eye doctors- In Memoriam Li Wenliang. Am J Ophthalmol. 2020. Doi:10.1016/j.ajo.2020.02.014.

2. Wei WE, Li Z, Chiew CJ, et al. Presymptomatic transmission of SARS-CoV-2 - Singapore, January 23-March 16, 2020. MMWR Morb Mortal Wkly Rep. 2020;69:411-415.

3. Rothe C, Schunk M, Sothmann P, et al. Transmission of 2019-nCoV infection from an asymptomatic contact in Germany. New Engl J Med. 2020;382:970-971.

4. Bai Y, Yao L, Wei T, et al. Presumed asymptomatic carrier transmission of COVID-19. JAMA. 2020;323:1406-1407.

5. Kimball A, Hatfield KM, Arons M, et al. Asymptomatic and presymptomatic SARS-CoV-2 infections in residents of a longterm care skilled nursing facility-King County, Washington, March 2020. MMWR Morb Mortal Wkly Rep. 2020;69:377-381

6. Whitehead S, Fiebel C. CDC Director on models for the months to come: this virus is going to be with us. National Public Radio. 2020. Available at: https://www.npr.org/sections/ health-shots/2020/03/31/824155179/cdc-director-on-models-forthe-months-to-come-this-virus-is-going-to-be-with-us. Accessed April 2, 2020

7. Xia J, Tong $\mathbf{J}$, Liu $\mathbf{M}$, et al. Evaluation of coronavirus in tears and conjunctival secretions of patients with SARS-CoV-2 infection. J Med Virol. 2020;92:589-594.

8. Wu P, Duan F, Luo C, et al. Characteristics of ocular findings of patients with coronavirus disease 2019 (COVID-19) in Hubei Province, China. JAMA Ophthalmol. 2020. Doi:10.1001/ jamaophthalmol.2020.1291.

9. Yu Jun IS, Anderson DE, Zheng Kang AE, et al. Assessing viral shedding and infectivity of tears in coronavirus disease
2019 (COVID-19) patients. Ophthalmology. 2020. Doi: 10.1016/ j.ophtha.2020.03.026.

10. Ophthalmology Fact Sheet from the National Ambulatory Medical Care Survey. National Center for Health Statistics. 2015. Available at: https://www.cdc.gov/nchs/data/namcs/ factsheets/NAMCS_2014_15_Opthalmology-508.pdf. Accessed April 1, 2020.

11. Rui P, Okeyode T. National Ambulatory Medical Care Survey: National summary tables. 2016. Available at: https://www.cdc. gov/nchs/data/ahcd/namcs_summary/2016_namcs_web tables. pdf. Accessed April 2, 2020.

12. Bennion JR, Wise ME, Carver JA, et al. Analysis of glaucomarelated mortality in the United States using death certificate data. J Glaucoma. 2008;17:474-479.

13. Sharma T, Salmon JF. Ten-year outcomes in newly diagnosed glaucoma patients: mortality and visual function. $\mathrm{Br} J$ Ophthalmol. 2007;91:1282-1284.

14. Centers for Disease Control and Prevention People who are at higher risk for severe illness. Coronavirus disease 2019 (COVID-19) 2020. Available at: www.cdc.gov/coronavirus/2019-ncov/needextra-precautions/older-adults.html. Accessed April 3, 2020.

15. Columbia University Department of Ophthalmology Columbia ophthalmology COVID-19 information. 2020. Available at: https:// www.columbiaeye.org/content/columbia-ophthalmology-covid19-information. Accessed March 31, 2020.

16. Centers for Disease Control and Prevention Coronavirus disease 2019 (COVID-19): how it spreads. 2020. Available at: www.cdc. gov/coronavirus/2019-ncov/prevent-getting-sick/how-covid-spreads. html. Accessed April 3, 2020.

17. Liebmann JM, Barton K, Weinreb RN, et al. Evolving guidelines for intracameral injection. J Glaucoma. 2020;29 (suppl 1):S1-S7.

18. Doshi RR, Leng T, Fung AE. Reducing oral flora contamination of intravitreal injections with face mask or silence. Retina. 2012;32:473-476

19. Garg SJ, Dollin M, Hsu J, et al. Effect of a strict 'no-talking' policy during intravitreal injection on post-injection endophthalmitis. Ophthalmic Surg Lasers Imaging Retina. 2015;46:1028-1034.

20. McCannel CA. Meta-analysis of endophthalmitis after intravitreal injection of anti-vascular endothelial growth factor agents: causative organisms and possible prevention strategies. Retina. 2011;31:654-661.

21. Centers for Disease Control and Prevention For healthcare professionals. Coronavirus disease 2019 (COVID-19). 2020. Available at: www.cdc.gov/coronavirus/2019-nCoV/hcp/index. html. Accessed April 3, 2020.

22. Centers for Disease Control and Prevention Steps healthcare facilities can take. Coronavirus Disease 2019 (COVID-19). 2020. Available at: www.cdc.gov/coronavirus/2019-ncov/healthcarefacilities/steps-to-prepare.html. Accessed March 31, 2020

23. Centers for Disease Control and Prevention Interim infection prevention and control recommendations for patients with suspected or confirmed coronavirus disease 2019 (COVID-19) in healthcare settings. Coronavirus disease 2019 (COVID-19). 2020. Available at: www.cdc.gov/coronavirus/2019-ncov/infection-control/ control-recommendations.html. Accessed April 1, 2020.

24. American Academy of Ophthalmology New recommendations for urgent and nonurgent patient care. 2020. Available at: www. aao.org/headline/new-recommendations-urgent-nonurgent-patientcare. Accessed March 31, 2020.

25. American Academy of Ophthalmology Coronavirus impact: practice operations and safety considerations. Available at: www.aao.org/ practice-management/article/coronavirus-practice-operationssafety-advice. Accessed April 3, 2020.

26. Centers for Disease Control and Prevention Strategies to optimize the supply of PPE and equipment. 2020. Available at: www.cdc. gov/coronavirus/2019-ncov/hcp/ppe-strategy/index.html. Accessed April 11, 2020.

27. Chodosh J, Holland GN, Yeh S. Important coronavirus updates for ophthalmologists. The American Academy of Ophthalmology. 2020. Available at: www.aao.org/headline/ alert-important-coronavirus-context. Accessed April 4, 2020. 
28. Columbia University Department of Ophthalmology COVID19 recommendations for practice operations. Available at: columbiaeye.org. Accessed March 8, 2020.

29. List N: Disinfectants for use against SARS-CoV-2. United States Environmental Protection Agency. 2020. Available at: www.epa. gov/pesticide-registration/list-n-disinfectants-use-against-sars-cov2. Accessed April 6, 2020.

30. Ragan A, Cote SL, Huang JT. Disinfection of the Goldman applanation tonometer: a systematic review. Can J Ophthalmol. 2018;53:252-259.

31. Junk AK, Chen PP, Lin SC, et al. Disinfection of tonometers: a report by the American Academy of Ophthalmology. Ophthalmology. 2017;124:1867-1875.

32. Nagington J, Sutehall GM, Whipp P. Tonometer disinfection and viruses. Br J Ophthalmol. 1983;67:674-676.

33. Atkins N, Hodge W, Li B. A systematic review regarding tonometry and the transmission of infectious diseases. $J$ Clin Med Res. 2018;10:159-165.

34. Pepose JS, Linette G, Lee SF, et al. Disinfection of Goldmann tonometers against human immunodeficiency virus type 1. Arch Ophthalmol. 1989;107:983-985.

35. Komatsu H, Inui A, Sogo T, et al. Tears from children with chronic hepatitis $\mathrm{B}$ virus (HBV) infection are infectious vehicles of $\mathrm{HBV}$ transmission: experimental transmission of $\mathrm{HBV}$ by tears, using mice with chimeric human livers. J Infect Dis. 2012;206:478-485.

36. Davanipour Z, Sobel E, Ziogas A, et al. Ocular tonometry and sporadic Creutzfeldt-Jakob disease (sCJD): a confirmatory case-control study. Br J Med Med Res. 2014;4:2322-2333.
37. Segal WA, Pirnazar JR, Arens M, et al. Disinfection of Goldmann tonometers after contamination with hepatitis C virus. Am J Ophthalmol. 2001;131:184-187.

38. Salvi SM, Sivakumar S, Sidiki SS. Use of disposable prism tonometry in routine clinical practice. Eye (Lond). 2005;19: $743-746$.

39. Britt JM, Clifton BC, Barnebey HS, et al. Microaerosol formation in noncontact "Air-Puff" tonometry. Arch Ophthalmol. 1991;109:225-228.

40. Sobolewska B, Buhl M, Liese J, et al. Slit lamps and lenses: a potential source of nosocomial infections? Eye (Lond). 2018;32: 1021-1027.

41. Sammons JS, Graf EH, Townsend S, et al. Outbreak of adenovirus in a neonatal intensive care unit: critical importance of equipment cleaning during inpatient ophthalmologic examinations. Ophthalmology. 2019;126:137-143.

42. Culham L. Single-use contact lenses aid imaging, diagnosis: multiple mirror, fundus, and retina lenses provide quality images. Optometry Times. 2015. Available at: https://www.optometrytimes. com/modern-medicine-cases/single-use-contact-lenses-aid-imagingdiagnosis. Accessed April 2, 2020.

43. Lee B, Szirth BC, Fechtner RD, et al. Are disposable and standard gonioscopy lenses comparable? J Glaucoma. 2017;26: e157-e159.

44. HAAG-STREIT AG. Stery Cup; 2020. Available at: www. haag-streit.com/fileadmin/Haag-Streit_Diagnostics/Disposables/ Brochures_Flyers/Sterycup/FLY_SteryCup_7200437-02030_Web_. pdf. Accessed April 2, 2020. 